\title{
Digital literacy in a post Coronavirus era: a management perspective for small businesses in Africa
}

\author{
Arachie Augustine Ebuka ${ }^{1}$, Hope Ngozi Nzewi ${ }^{2}$, Emejulu Gerald ${ }^{3}$, Kekeocha Mary Ezinne ${ }^{4}$ \\ Department of Business Administration, Nnamdi Azikiwe University, Awka, Nigeria 1,2,4 \\ Department of Cooperative Economics and Management, Nnamdi Azikiwe University, Awka \\ Nigeria $^{3}$ \\ ae.arachie@unizik.edu.ng ${ }^{1}$,hn.nzewi@unizik.edu.ng ${ }^{2}$, ga.emejulu@unizik.edu.ng ${ }^{3}$, \\ me.kekeocha@unizik.edu.ng ${ }^{4}$
}

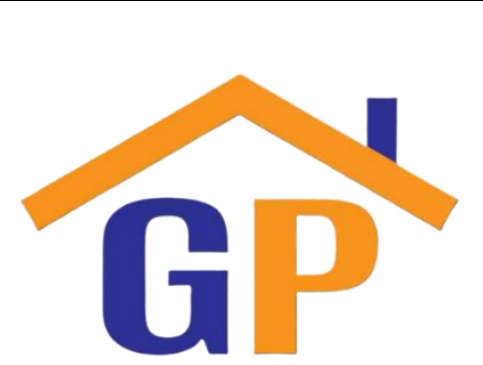

Article History

Received on 17 January 2021

Revised on 2 February 2021

Accepted on 8 February 2021

\begin{abstract}
Purpose: This study examined how small businesses in Africa can use technology to grow and sustain their businesses in a post-Covid19 world. The paper looked at various digital skills needed by these businesses to navigate and profit from the digital space's massive opportunities. It also ascertained the challenges facing them from keying into the digital ecosystem. The place of technology in the fight against Covid-19 was also highlighted.
\end{abstract}

Research methodology: This study is a qualitative review study.

Results: The study concluded that possessing some form of digital skills by business owners and employees could be the difference between a competing and a non-competing organization.

Limitations: The work did not use methodology as it is a qualitative review study that limited the study's generalizability.

Contribution: This work represents a current work in digital technology and how it relates to pandemic situations and economic challenges, especially in Africa.

Keywords: Digital, Technology, Covid-19, Small businesses, Management, Skills

How to cite: Ebuka, A. A., Nzewi, H. N., Gerald, E., \& Ezinne, K. M. (2020). Digital literacy in a post Coronavirus era: a management perspective for small businesses in Africa. Annals of Management and Organization Research, 1(3), 203-212.

\section{Introduction}

\section{Background of the study}

The world today is increasingly becoming more technologically inclined than ever before. The quest to be digitally propelled did not start recently; it has been on the cards for quite some time. In an alliance with this, Campbell (2006) aver that digital technology has pervaded every aspect of our civilization. It has since changed not just how we store and transmit recorded knowledge, historical records, and a host of other kinds of communication. However, it has also revolutionized how we seek and gain access to these materials. Similarly, Martin (2006) opines that the 21st-century world is digitally infused: a world influenced and guided by electronic technology's effects and products in different facets.

A digital world needs digital or technology (tech) savvy people to help navigate the numerous challenges and opportunities presented by digitization. Digital technologies play an important role in this digital age (Kaeophanuek, Na-Songkhla \& Nilsook, 2018). Hence, organizations are not just looking for employees who are only competent in their areas of specialties, but those who can spice up their competencies with tech-savviness. Boyaci and Atalay (2016) posit that the current workplace requires employees who can research and structure information by applying critical thinking skills, resolve problems using their knowledge and experience, be creative innovators, and exhibit effective communication and cooperation abilities. Digital skills are vital to participating in the knowledge 
society and become an essential element for facilitating employment (van Deursen \& van Dijk, 2011). In an age where Information and Communication Technology (ICTs) predominate, people need the capabilities to thrive in and beyond education (Littlejohn, Beetham \& McGill, 2012). That is why in most adverts, multinational organizations, while placing adverts, state that competencies in tech areas or those who are amenable to learn gives such an applicant an added advantage.

Digital skills are learnable if one is open to be taught. Hence, some of the people who are making waves in the technology space are not necessarily those who read or studied it, but those who learned it one way or another. Hence, the ability to learn is a critical asset to people. Tinio (2002) avers that the illiterates of the 21st century are not those who cannot read and write, but those who cannot learn, unlearn and relearn. When one learns a digital skill, such a person could be said to be digitally literate in that aspect, because being literate has to do with the ability to do something well with little difficulty. Being digitally literate means navigating through some of the digital tasks with ease, having the skillset and the competencies to operate, create and use digital devices and contents. Hiller, Casey and Shea (2017) state that digital literacy involves any digital reading and writing techniques across multiple media forms, including words, texts, visual displays, motion graphics, audio, video, and multimodal forms. It is a combination of technical-procedural, cognitive and emotional-social skills (Aviram \& Eshet-Alkalai, 2006).

Technology has been critical in building sustainable economies for countries. Businesses have also gained massively in different ways using technologies. These gains are more evident within the period of a complete shutdown of economies due to the battle against the spread of Corononavirus (Covid-19). The outbreak and the rampant spread of the virus resulted in many nations shutting down their economies through various lockdown procedures and measures to prevent mass gathering and the concomitant spread. World Health Organization (WHO) (2020) aver that the virus is transferred from person to person via basic social gestures like face to face communication, handshake, or touching an infected surface; hence lockdown was embraced by many countries. Social distancing and staying at home are the best solutions to avoid this virus's further spread (Bhavya \& Sambhav, 2020). This made businesses shut down operations with its catastrophic effects on the businesses and the economies.

In the face of all the measures to keep the virus from rapidly spreading and the loss of millions of lives, technology and innovations were challenged and seemed to have helped salvage a certain aspect of the world's economies. They played a major role in ensuring that businesses did not go entirely under the radar by providing opportunities for organizations and their customers or clients to meet online and transact. Many businesses, government agencies and ministries met, interacted and executed projects virtually as online meetings, conferences and seminars became like the norm in the face the biting effect of the lockdown. Bhavya and Sambhav (2020) put it thus: technologies and its components became something like a life savior during COVID-19. Before now, the deployment of technology helps companies perform better as captured by van Deursen and van Dijk (2011). They aver that ICT usage increases revenue growth, workplace productivity, and competitiveness while fostering innovativeness of organizations. A fact made even more pronounced during the peak of Covid-19.

Multinationals and big corporations have since embraced and deployed ICT and innovations in certain aspects of their processes and procedures. This situation is entirely opposite for small businesses, primarily in Africa where lack of vision, skills and competencies hamper ICT deployment in organizations. The poor state of enabling infrastructures adds to the encumbrances to technology adoption and adaption in small businesses. This might make the recovery processes of these sorts of businesses in Africa slower than their counterparts in developed climes. Thereby necessitating this study to ascertain the role digital literacy could play in navigating the huddles of a post-covid-19 world through the lenses of managing small businesses in Africa.

\section{Statement of the problem}

A $21^{\text {st }}$-century economy is a knowledge-based economy supported by rapid technological integration in many aspects of our private lives and a constant thrust of organizations' existence. To continue fuelling this rapid technological injection, an army of digitally savvy business owners and employees are sacrosanct. The rapid integration of new ICTs has meant that continuously evolving skills are needed 
to deploy such technologies (Ananiadou \& Claro, 2009; Janssen, Stoyanov, Ferrari, Punie, Pannekeet \& Sloep, 2013). However, managers and owners of small business in Africa seem not to have gotten a handle on the situation as they appear not to have given digital literacy the pride of place it craves for their businesses' sustainability. Asset sadly is still considered to be finance, machinery and properties; intellects are to some extent considered an asset in Africa, but the place of digital asset, skills and competences is still undefined and unappreciated. This is a reason expenditure is still heavily skewed towards equipment purchase, training of personnel on the usage of such equipment, promotions and advertising, physical contact and the rest in many small businesses in Africa. Owners and manager of small business in Africa seem to still be focused on paper qualifications of employees and potential employees, they also consider their work experience and intellectual prowess. Little seems to be done by management and owner to consider potential employees' digital competences to have an in-house digital person as against hiring an outsider when the company needs services like a graphic designing, digital/social media marketing, and the rest. These skills are critical in the online marketing space and sadly, small businesses in Africa are yet to consider them as employability skills. It is against this backdrop that this study was deemed necessary to explore how some of these sorts of digital skills could help raise small businesses' performance in a post-covid-19 world.

\section{Objectives of the study}

This study's broad objective is to ascertain how digital literacy can help small businesses in Africa in the post-covid-19 era. Specifically, this study seeks to:

i. Explore various digital skills necessary for small businesses in Africa to remain competitive in a post-covid-19 era.

ii. To investigate some challenges facing small businesses in Africa to adopt ICT in their operations.

\section{Review of related literature}

\subsection{Digital literacy}

The debate about the concept of digital literacy has been on for quite some time now, it started as early as the 1990s (Kaeophanuek, Songkhla \& Nilsook, 2018). The term digital literacy has two words combination, "Digital" and "Literacy." However, the meaning of the two words combined is much deeper than marrying the individual words together. This was the position of Warschauer and Tina (2010), who opine that digital literacy 'is the marrying of the two terms, digital and literacy; however, it is much more than a combination of the two terms. The word digital as a standalone word, entails technology, its application, and the components used in applying it, including applications and software.

On the other hand, literacy has to do with the ability and competence to comprehend and explain something with ease. It is the ability to understand something more profound than others and use it to solve real-world problems and define how literate someone is at something. Therefore, the combination of the two words means the capacity to use various technologies, applications, and software with ease. It is the competency to create, use and communicate in a digitally controlled environment. A digitally literate person has to have the capacity to use technology to solve real-world problems. This was captured by Jun and Pow (2011) who posit that individuals with digital literacy skills should be able to use technology in management, evaluation and communication.

To be digitally literate entails using a wide range of digital technologies to create, search and communicate solutions to others. It can effectively and critically navigate, evaluate and create information using a range of digital technologies (Jenkins, 2009). Bawden (2008) sees it as the set of attitudes, understanding, and skills to effectively handle and communicate information and knowledge in various media and formats. Using digital technology, communication tools, or networks to locate, evaluate, use and create information to evaluate problems and create actionable solutions defines a person's literacy level digitally (Bell \& Shank, 2008).

Digital literacy is not just the competence to use other people's inventions such as applications and software to proffer solutions. However, it also entails creating apps and software and communicating the same, clearly in a manner that will allow others to use it. Hiller, Casey and Shea (2017) aver that 
digital literacy does not just stop at solving problems with other people's innovations and ingenuities, but also having the insight to create content and build solutions in different forms to come out of difficult situations. Also crucial in the whole dynamics of digital literacy is the competence to search for, locate and sieve useful information and solutions from the not-so-suited ones. The digital space is filled with multiple data, information and solutions to similar problems, so, having the capacity to select the ones most suitable to a particular problem is also skill on its own. It could define a person's literacy level digitally.

\subsection{Coronavirus (Covid-19)}

The story of Coronavirus started in 2019 in the Wuhan province of China. It came with many challenges and, ultimately, deaths. It was first identified as severe acute respiratory syndrome coronavirus 2 (SARS-CoV-2). The World Health Organization (2020) declared it a Public Health Emergency of international concern on 30 January 2020 and a pandemic on 11 March of the same year. This virus is life-threatening and has dreadfully caused many deaths (Bhavya \& Sambhav, 2020).

It has been associated with other families of viruses such as Severe Acute Respiratory Syndrome (SARS) and some types of common. Research and studies have shown that it is a completely new strain in the family of Coronavirus that has been known before, leading to its being called the "novel coronavirus." The United Nations Development Programme (2020), as a result of its novelty, said that we are in uncharted territory regarding covid-19.

The virus is spread primarily through close contact, often via small droplets produced by coughing, sneezing, and talking. Spread is possible before symptoms appear and in people who do not show symptoms $(\mathrm{WHO}, 2020)$. The virus spread from person-to-person via direct contact with respiratory droplets of someone infected, generated through coughing and sneezing, and touching surfaces contaminated with the virus (Ojiagu, Nzewi \& Arachie, 2020).

At the peak of the first wave of the virus, specific measures were introduced and observed by various nations, organizations and individuals. Some of such measures are:

1. Regular hand washing in flowing water.

2. Covering of mouth when coughing or sneezing with a bent elbow.

3. Two meters distancing from people termed "social distancing".

4. Putting on nose masks in public or crowded places

5. Disinfecting surfaces.

6. Increasing ventilation and air filtration indoors.

7. Self-isolation for infected people or those who suspect they have been infected.

8. Lockdown of activities.

9. Introduction of virtual meetings.

\subsection{Covid-19 and digital technology}

At the peak of the first wave of the spread and contamination of the virus, various world governments resorted to shutting down the government and private businesses' activities; movement was restricted to prevent mass gathering and contact with infected people, which will tantamount to more spread. These had effects on the economies of the world and businesses suffered at various degrees as many nations, including African countries like Nigeria and Ghana went into recession (Nigeria Bureau of Statistics, 2020). However, technology came to the rescue of many people, businesses and government as more and more activities went online and conducted virtually. Meetings were held online, and businesses created online shops and customers placed orders online and got supplied with minimum contact. Therefore, technology played and is still playing a significant role in ensuring that the virus's effect is minimal.

Many countries of the world have technologies in different areas that will help fight the spread and navigating through the hardship occasioned by many measures put in place by the government of different nations. Technologies such as 3D printing for ventilators for treatment of corona victims (Gelles \& Petras, 2020), big data (Nawaz, 2019) for workers, employee, patients etc., artificial 
intelligence (AI)-based orthopedics (Haleem, Vaishya \& Javaid, 2019) are all coming on stream during this period. Khan securities in health care industries and robots operating many human jobs are all technologies being deployed to tackle the pandemic (Manogaran, Thota, Lopez \& Sundaraseka, 2017)

BlueDot's, a Canadian start-up developed an Artificial Intelligence (AI) based algorithm that analyzes all government news, reports, and social media for tracking COVID-19 infections. The e-commerce giant has also developed an AI-based system that can detect Coronavirus within 20 seconds with $96 \%$ accuracy, which takes a minimum of 15 minutes (Bhavya \& Sambhav, 2020). Robots are used to clean, disinfect, and deliver materials and food to reduce contact, which will curtail the virus's spread (Bhavya \& Sambhav, 2020). Other technologies used are telemedicine/telehealth, which enables patients to consult well-trained professionals on their medical conditions through digitally propelled platforms, thereby avoiding coming to the hospital, which was filled up in some countries in the heat of the pandemic. On the other hand, telehealth allows patients to be seen and diagnosed remotely by doctors via different technological setups. Blockchain technology also came in handy as it helped provide realtime data and information to the people who need it and make traceability in disease control seamless. It also plays a role in the effective management of the supply chain and providing a robust, transparent decision-making process and, as a result, could lead to faster responses during emergency periods.

Fifth Generation $(5 \mathrm{G})$ and smart applications have also been of great help in this period. The high-speed network provided by $5 \mathrm{G}$ allows real-time video and audio quality data for patient data analysis, telemedicine, medical, and surgical intervention. Similarly, drones were also of immense help for the fight against Covid-19. Drones, which are unmanned devices, controlled in a remote location, can undertake logistics providers and area surveillance jobs and can also disinfect strategic and suspected infectious locations. From disinfection and street patrols to food and medicine delivery in quarantined districts, drones were deployed in the front line to contain the virus's spread.

To maintain contact with friends, families and clients at the peak of the disease's spread, some Applications (Apps) came in handy. Among the most used Apps are Zoom, Microsoft Teams, WhatsApp, Google Duo, Skype and WebEx. These Apps made it possible for people to interact virtually and not feel the effect of the restriction of movement and shutdown put in place at that period. These Apps were and also continue to be at the forefront of virtual meetings for government and its officials, multinational corporations and big businesses. Some small businesses deploy such Apps for their conferences and seminars. Therefore, technology is crucial at this time. However, one thing is having the technology to accomplish so much; another thing is having the skills and the competencies to handle the technologies, so digital literacy and skill are sacrosanct at this critical moment of human existence.

\subsection{Digital Skills for sustainable small businesses in Africa}

Businesses around the world are increasingly making the internet their market place and base. This is because there is an unimaginable customer base on the internet as roughly 4.66 billion people were using the internet worldwide in October 2020, that is over $60 \%$ of the world's population (https://datareportal.com/global-digital-overview; https://www.statista.com/statistics/617136/digitalpopulation-worldwide/). Online businesses are not impeded by time and space, as people can view and access business profile within seconds and place an order or contact you with equal alacrity. Hence, businesses that will be sustainable tomorrow may have one sort of online presence or the other. However, to achieve this online presence, they need to have people with the right digital skills to navigate the sometimes intimidating online ecosystem. Therefore, bringing to the fore the immense importance of digital skills.

Researchers around the world have pinpointed the indispensability of digital literacy from their findings. ICTs (connectivity-tools) have been found helpful in reducing the problems of 'isolation' (Tinio, 2002; Vrana, 2007) and 'disempowerment' (Macleod, 2005; Wims \& Lawler, 2007) for the developing countries and marginalized groups. Digital literacy is not only shifting power bases in the developing countries from "elites to masses (Macleod, 2005)", but is increasingly "perceived as a survival skill (Aviram \& Eshet-Alkalai, 2006). It helps people communicate and keep up with societal trends and hence, it is something of a norm today (Emiri, 2015). 
Skills needed by individuals and businesses are numerous, as one could have literacy in an aspect, but completely oblivious of or illiterate in other aspects. However, for businesses to create a sustainable online presence through digital technologies, some skills are sacrosanct. Hence, small businesses and their owners need to have some of these skills or employ those who do or consult them to create a digital experience for their businesses. Some of the skills pertinent to actualize an online existence for small businesses are as follows:

- ICT gadget handling skills: the first and probably an essential skill needed by small business owners is using various gadgets such as smartphones and laptops. This is because every other skill might be said to be dependent on it.

- Web design skills: this is the setting up an online shop where people can visit and get business information. Having this skill is very important as it will save much cost in paying people to design and maintain them.

- Graphics designing: online marketing or selling thrives on appealing to people visually. There is no other way to appeal to people if not by showing them how amazing your business, products and services are, and graphic design is at the forefront of making this happen.

- Digital/Online marketing: one thing is designing a website or graphically designing products and or services; another thing has the skill to advertise and market such product and or services to the public. This is where digital, or as some people, online marketing, comes into play. So, this is an essential skill for the business owners of today or their employees.

- Copywriting: this is the act of making people take action through writing. The skill that deals with appealing to people to inquire and patronize product or service through writing.

- Creating links: the act of creating links that will be shared to customers and prospective customers to direct them to the product and or services easily is an important skill for a sustainable online marketing and selling experience.

- Search Engine Optimization (SEO): having an online presence is essential, but driving traffic to, and marking sure that your products and or services rank high when people search for a similar product and or services is a great skill to have. When people search for products online and business do not pup-up, it can not generate sales. So SEO is the skill of organically or inorganically making your organization, services or product rank high when searched online.

- Editing skills: having the skill to edit videos, audios and pictures will be an added advantage to anybody who wants to master or go into online sells.

- Internet usage skills: having the internet is one thing, but knowing how to use it is another. We are most times inundated with many materials, information and data about something. Sometimes, these pieces of information or data are conflicting. Thus, knowing where to search and how to sieve the needed information from the noise (others that may not be needed) is a skill on its own. Some persons may be searching for information and may not find it, while someone with the skill to search online will find more information than is needed for the same issue.

- Content creation: consuming what other people created is good, but having the skill to create content that others will consume is also a top skill needed. This is because online customers need to be fed with product information regularly. Otherwise, they may get bored and move over to a more lively and engaging organization that creates good content.

- Social media handling and management skills: social media is a vast global market with huge potential for those with the right kind of skill to harness it. Business owners with the skill to use their various social media handles to communicate, advertise and close deals will go far in the $21^{\text {st }}$-century world.

Other high-end skills necessary for massive progress in a digital age for small business are as follows:

- Computer programming.

- Software building.

- Digital data science and analysis. 
- Artificial Intelligence.

- Online payment deployment and digital currency navigation.

- Application building.

- Digital project management.

- Digital design and data visualization.

- Digital business analysis and simulations.

\section{Encumbrances to Technological Adaptation in Africa}

Small businesses in Africa are met with many challenges in digitizing their operations to create a sustainable online presence. Some of the problems are surmountable by themselves, while others are systemic and endemic due to a toxic operational environment of business in Africa.

- Change challenge: some people believe in doing things the old ways because they feel it is better and more convenient. Telling them to change from the traditional mortar and brick shop system, radio, television and physical advertising to online shops and advertising may be difficult for them to comprehend and accept.

- Culture: the culture of some Africans is such that abhors westernization as they refer to it. They feel that it is not their way of doing things and against their belief system and culture. This also constitutes a significant challenge for businesses to embrace digitization and online experience.

- Access: the challenge of access is multifaceted. It could be access to the gadgets needed to actualize online participation, and it could also be access to affordable internet facilities. Access could also be seen in allowing people to participate fully in online experience as some governments restrict access and participation of their citizens or censor content on the internet. This presents a challenge as some business owners may be discouraged from participating in such a cagy system.

- Education: the education, comprehension and assimilation level of small business owners in Africa is deficient in inculcating digital marketing doctrine into their business models.

- Customers' perception: some customers in Africa prefer patronizing physical shops and marketing to online marketing. This is partly because of scammers' fraudulent activities online where some of them may have fallen victim. This is also an encumbrance to embracing digital platform for product or service delivery.

- Cost: the cost associated with acquiring some digital skills may be discouraging. It is not just capital cost but also the cost associated with time. Often, a lot of time is needed to be devoted to learning the necessary skills, and sometimes, small business owners may opine that they do not have the luxury of time.

- Opportunity to Learn: some of the business owners who may be willing to learn may not find the opportunity to do so, this may be due to not finding a suitable place to learn the skill they require.

- Awareness: sometimes, the level of awareness of some of the small business owners is very shallow. They may be operating their business in remote places where the literacy level is very low, affecting them. So, it might be difficult to know the skills needed and where to get them without awareness.

- Openness: the openness to learn and unlearn for some small business owners is very poor. They often time choose to cling to the old and comfortable way of doing things.

- Access to the internet: Africa and some other developing countries still have internet penetration issues in most rural areas. This may present a huge challenge because, without the internet, digital skills and online marketing and trading may achieve the required result.

- Electricity Challenge: electricity could be said to be the biggest challenge of most small business in Africa, as they battle with epileptic power supply almost daily. They spend so much on providing their own power, and may not be left with enough money for other sustainable engagement forms like digital skill acquisition and the likes. 


\section{Empirical review}

Various authors have carried out some empirical studies in different countries on digital literacy and other constructs. The essence of this empirical study is to see what others have done in digital literacy, how they did it and their findings. Among some of the studies are:

Laar, Deursen, Van Dijk and Haan (2019) carried out a study to see if previously cited twenty-firstcentury digital skills are suited to the creative industries workforce and investigate the extent to which skill development gets attention in current organizational practices. The researchers conducted in-depth interviews with a sample of 24 managers and senior executives of creative organizations based in the Netherlands. The findings showed and supported the relevance of twenty-first-century digital skills in the organizations studied; however, there seems to be insufficient attention to these skills' levels; they play a minor role in selecting and evaluating procedures.

Kaeophanuek, Na-Songkhla and Nilsook (2018) studied Thai university library and information sciences instructors' and students' opinions on teaching and learning environments to develop digital literacy skills. The tools used for the study were digital literacy self-assessment and in-depth interviews. Findings from the study indicated that 400 students from across Thailand considered their abilities for digital tools usage good and considered their information and digital transformation skills to be at an intermediate level. Also, they found out from the interviews with the instructors, information about teaching environments, problems and obstacles, and alternative methods for Information Sciences students' digital literacy development.

Emiri (2015) studied Nigeria's digital literacy skills among librarians in university libraries in the 21 st century. The study adopted a descriptive survey design with a population of all librarians from university libraries in Edo and Delta States. A questionnaire instrument was used to collect data and was analyzed using simple percentages and frequency count. Emanating from the findings is that electronic mailing, social networking, PDAs, mobile phones and internet surfing are the major Digital Literacy Skills (DLS) amongst librarians. The study also revealed that librarians acquired DLS through colleague's assistance, trial and error, IT programmes, and formal education.

Ojeomogha (2019) carried out a study in Lagos State Nigeria to assess digital literacy's effect on small scale business owners' entrepreneurial returns. A survey research design was deployed for the work and the instrument for data collection was a structured questionnaire. The study was carried out on 250 small business owners in the informal sector in Lagos State. Data analysis was carried out using ANOVA and regression methods. The findings indicated that digital literacy greatly influences entrepreneurial returns of small scale business owners in Lagos State.

Erlanitasari, Rahmanto and Wijaya (2019) in Indonesia analyzed the Go Online SMEs Movement program launched by the government from 2017 until the present period. The qualitative content analysis method was used in work; hence, primary data online portal research was deployed through the Google search engine. On the other hand, secondary data were collected from government publications about the program. Findings revealed that only 36\% of SMEs in Indonesia are still finding it difficult with conventional marketing. Also revealed is that only $37 \%$ of SMEs are equipped with essential online marketing capabilities, $18 \%$ have medium online capacity while $9 \%$ have sophisticated digital marketing capacity.

From the empirical reviews carried out, it could be deduced that digital literacy affects the performance of SMs as reported by Laar, Deursen, Van Dijk and Haan (2019) who twenty-first-century digital skills relevant and essential to organizations studied. Similarly, Ojeomogha (2019) indicated that digital literacy greatly influences small scale business owners' entrepreneurial returns. All these are pointers towards the fact the digital skills are essential. However, none of the studies looked at how these skills could help businesses manage the effect of covid-19 better and how to use it to navigate through the various protocols to be observed to prevent the further spread of the virus, which is a gap this study intends to fill. 


\section{Conclusion}

Covid-19 came with many challenges for people, organizations, and government due to the various measures adopted to prevent or curtail the virus's spread. Millions of people lost their lives, others lost their source of livelihood while many businesses closed shop. However, amid the virus's chaos, digital skills and literacy rescued some of the situations as many activities that would have hitherto been thwarted were orchestrated over the internet. Meetings were held, organizations continued operations and delivering services and products due to the opportunities made possible by digital technologies. Therefore, possessing some form of digital skills by business owners and employees could be the difference between an organization that might go under and organizations that would stay afloat. Having such skills could confer a tremendous competitive edge on those that have it. It is therefore concluded that going forward, digital skill is pertinent for the survival of all forms of businesses in Africa and the world over.

\section{Recommendations}

The following recommendations are put forward:

a) Small business owners and managers should focus more on employees' digital skills and potential employees when hiring. This will go a long way in reducing hiring consultants' cost to do the job of creating an online presence for the business.

b) Training and retraining of employees and management should be digitally focused to stay ahead of the ever dynamic local and global business environment.

\section{References}

Ananiadou, K., \& Claro, M. (2009). 21 st century skills and competences for new millennium learners in OECD countries. OECD Education Working Papers, 41. DOI: https://doi.org/10.1787/218525261154, accessed 30 December 2018.

Aviram, A., \& Eshet-Alkalai, Y. (2006). Towards a theory of digital literacy: three scenarios for the next steps. European Journal of Open, Distance E-Learning. [Online]. Available from: http://www.eurodl.org/.

Bell, T., \& Shank, J. (2008). Digital literacy, definition and resources. What is digital literacy? http://cleach.wordpress.com/what-is-digital-literacy/ Accessed 10/03/12

Bhavya, R., \& Sambhav, S. (2020). Role of mobile communication with emerging technology in COVID'19. Advanced Trends in Computer Science and Engineering, 9(3), 3338-3344.

Boyaci, Ş. D. B., \& Atalay, N. (2016). A scale development for 21 st century skills of primary school students: A validity and reliability study. International Journal of Instruction, 9(1), 133-148.

Campbell, J. D. (2006). Changing a cultural icon: the academic library as a virtual destination. www.eric.ed.gov/ERICWebPortal/recordDetail?accno. Accessed 13/05/12

Bawden, D. (2008). Origins and concepts of digital literacy. Digital literacies: concepts, policies and practices. New York: Peter Lang Publishing, 17-32.

Emiri, O. T. (2015). Digital literacy skills among librarians in university libraries in the 21st century in Edo and Delta states, Nigeria. International Journal of Scientific \& Technology Research, 4(8), 153-159.

Erlanitasari, Rahmanto \& Wijaya (2019). Digital economic literacy micro, small and medium enterprises (SMES) go online. Informasi, 49(2), 145-156.

Gelles, K., \& Petras, G. (2020). How ventilators work and why Covid-19 patients need them to survive coronavirus USA Today.

Haleem, A., Vaishya, R., Javaid, M., \& Khan, I. H. (2019). Artificial Intelligence (AI) applications in orthopaedics: an innovative technology to embrace J Clin Orthop Trauma, 10.1016/j.jcot.2019.06.012.

Hiller, A. S., Casey, M. P., \& Shea, N. K. (2017). Digital literacy for the 21st century encyclopedia of information science and technology, fourth edition. Published in the United States of America by Igi global information science reference (an imprint of IGI Global). DOI: 10.4018/978-15225-2255-3.ch194 overview\#: : text=Roughly\%204.66\%20billion\%20 people\%20around,twelve\%20months\%20to\%20October\%202020 (retrieved 05/01/2021). 
Janssen, J., Stoyanov, S., Ferrari, A., Punie, Y., Pannekeet, K., \& Sloep, P. (2013). Experts' views on digital competence: commonalities and differences. Computers \& Education, 68, 473-481.

Jenkins, H. (2009). Confronting the challenges of participatory culture: Media education for the 21st century. Cambridge, MA: MIT Press.

Jun, F., \& Pow. J. (2011). Fostering digital literacy through web-based collaborative inquiry learning-a case study. Journal of Information Technology Education, 10.

Kaeophanuek, S., Na-Songkhla, J., \& Nilsook, P. (2018). How to enhance digital literacy skills among information sciences, students. International Journal of Information and Education Technology, 8(4), 292-297.

Laar, E. V., Deursen, A. J.A.M., Van Dijk, A. G. M., \& Haan, J. (2019). Twenty-first century digital skills for the creative industries workforce: Perspectives from industry experts. First Monday, 24(1-7).

Littlejohn, A., Beetham, H., \& McGill, L. (2012). Learning at the digital frontier: A review of digital literacies in theory and practice. Journal of Computer Assisted Learning, 28, 547-556.

Macleod, H. (2005). What role can educational multimedia play in narrowing the digital divide?, Int. J. Edu. Dev. using ICT, 1(4). [Online] Available from: http://ijedict.dec.uwi.edu//.

Manogaran, G., Thota, C., Lopez, D., \& Sundaraseka, R. (2017). Big data security intelligence for healthcare industry 4.0. Cybersecurity for Industry, 4.0, Springer, Cham, 103-126.

Martin, A. (2006). A European framework for digital literacy, Digital Kompetanse, 2, 151-161.

Nawaz, N. (2019). Artificial Intelligence interchange human intervention in the recruitment process in Indian software industry. 2019 International Journal of Advanced Trends in Computer Science and Engineering (IJATCSE), 8(4).

Ojeomogha, T. O. (2019). Digital literacy and entrepreneurial returns among small business owners in Lagos State, Nigeria. Education \& Science Journal of Policy Review and Curriculum Development, 9(2), 1-11.

Ojiagu, N. C., Nzewi, N. H., \& Arachie, A. E. (2020). Accountability and transparency in nation building: a covid-19 experience in sub-Saharan Africa. International Journal of Public Policy and Administration Research, 7(1), 23-33. https://www.statista.com/statistics/617136/digitalpopulation-worldwide/ (retrieved 05/01/2021).

Tinio, V. L. (2002). ICT in education, in proceedings of UNDP for the benefit of participants to the World Summit on the Information Society, UNDP's regional project, the Asia-Pacific Development Information Program (APDIP), in association with the secretariat of the Association of Southeast Asian Nations (ASEAN). [Online] Available from: http://www.apdip.net/publications/ iespprimers/eprimer-edu.pdf.

United Nations Development Programme. (2020). Covid-19 pandemic: Humanity needs leadership and solidarity to defeat the Coronavirus. Retrieved from: https://www.undp.org/content/undp/en/home/coronavirus.html.

van Deursen, A. J. A. M., \& van Dijk, J. A. G. M. (2010). Measuring internet skills. International Journal of Human-Computer Interaction, 26(10), 891-916.

Vrana, I. (2007). Changes required by ICT era are painful sometimes, In Proceedings of CAUSE98, an EDUCAUSE conference, [Online] Available from: http://www.educause.edu/copyright.html.

Warschauer, M., \& Tina, M. (2010). New Technology and digital worlds: analyzing evidence of equity in access, use, and outcomes. Review of Research in Education 34, 179-225.

Wims, P., \& Lawler, M. (2007). Investing in ICTs in educational institutions in developing countries: An evaluation of their impact in Kenya. Int. J. Educ. Dev., using ICT, 3(1). [Online] Available from: http://ijedict.dec.uwi.edu/l.

World Health Organization (2020). Director-General's opening remarks at the media briefing on Covid-19. (Press release). 11 March 2020. Available online: https://www.who.int/dg/speeches/detail/who-director-general-s-opening-remarks-at-themedia-briefing-on-covid-19- --11-march-2020.

World Health Organization (2020). Q\&A on Coronaviruses (Covid-19). Available online: https://www.who.int/emergencies/diseases/novel-coronavirus-2019/question-and-answershub/q-a-detail/q-a-coronav viruses.

World Health Organization (WHO) (2020). Coronavirus disease (covid-19) advice for the public. https://www.who.int/ emergencies/diseases/novel- corona virus - 2019/ advice- for-public2020. 